Jurnal Ilmu Sosial dan Pendidikan (JISIP)

Vol. 6, No. 1 Januari 2022

e-ISSN : 2656-6753, p-ISSN: 2598-9944

DOI: 10.36312/ jisip.v6i1.2698/http://ejournal.mandalanursa.org/index.php/JISIP/index

\title{
Wacana Bukan Muhrim Pada Tayangan Video Cokro Tv (Sebuah Analisis Wacana Kritis)
}

\author{
Wuriy Handayani ${ }^{1}$, Yumna Rasyid ${ }^{2}$, Miftakhulhairah Anwar ${ }^{3}$ \\ ${ }^{1}$ Perbanas Institute \\ ${ }^{2,3}$ Universitas Negeri Jakarta
}

\begin{tabular}{l}
\hline Article Info \\
\hline Article history: \\
Received: 08 Desember 2021 \\
Publish: 02 Januari 2022
\end{tabular}

Keywords:

Critical Discourse Analysis

Exclusion and inclusion

Ideology

\section{Info Artikel}

Article history:

Diterima: 08 Desember 2021

Publis: 02 Januari 2022

\begin{abstract}
The speaker on Cokro TV's Youtube video, Ade Armando, expressed his opinion about the discourse of non-mahram which has invited controversy. The discourse of non-muhrim has sparked debate because it is associated with social problems that occur in society, namely choosing a doctor who is adjusted to the gender of the patient. This research emphasizes more on the ideology that the speaker wants to convey and the strategies used by the speaker to express his ideology. The critical analysis model used in this research is Van Leeuwen's critical analysis model. This research model is used to determine the social actors supported and marginalized by the speaker. This research uses a qualitative research approach with content analysis method. The results showed that the speakers used exclusion and inclusion strategies. The exclusion strategy used by the speaker leads to a passive discourse strategy, while the inclusion strategy used by the speaker leads to an identification discourse strategy.

\begin{tabular}{l}
\hline ABSTRAK \\
Pembicara dalam video Youtube Cokro TV, Ade Armando, mengungkapkan \\
pendapatnya tentang wacana non-mahram yang mengundang kontroversi. Wacana \\
non-muhrim sempat memicu perdebatan karena dikaitkan dengan masalah sosial \\
yang terjadi di masyarakat, yakni memilih dokter yang disesuaikan dengan jenis \\
kelamin pasien. Penelitian ini lebih menekankan pada ideologi yang ingin \\
disampaikan pembicara dan strategi yang digunakan pembicara untuk \\
mengekspresikan ideologinya. Model analisis kritis yang digunakan dalam \\
penelitian ini adalah model analisis kritis Van Leeuwen. Model penelitian ini \\
digunakan untuk mengetahui aktor-aktor sosial yang didukung dan dipinggirkan \\
oleh penutur. Penelitian ini menggunakan pendekatan penelitian kualitatif dengan \\
metode analisis isi. Hasil penelitian menunjukkan bahwa pembicara menggunakan \\
strategi eksklusi dan inklusi. Strategi eksklusi yang digunakan penutur mengarah \\
pada strategi wacana pasif, sedangkan strategi inklusi yang digunakan penutur \\
mengarah pada strategi wacana identifikasi.
\end{tabular}
\end{abstract}

This is an open access article under the Lisensi Creative Commons AtribusiBerbagiSerupa 4.0 Internasional

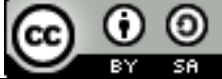

Corresponding Author:

Wuriy Handayani,

Perbanas Institute

Email: wuriyhandayani_9906921001@mhs.unj.ac.id

\section{PENDAHULUAN}

Salah satu kasus yang mengundang kontroversi dan banyak pendapat adalah kasus bukan muhrim. Kasus ini berkaitan dengan sebagian kaum muslim yang memutuskan untuk tidak meminta bantuan dari yang bukan muhrimnya. Misalnya ketika seorang wanita yang sedang sakit ataupun sedang hamil memutuskan untuk tidak memeriksakan kesehatannya ke dokter pria karena dianggap bukan muhrimnya. Hal ini tentu saja akan membahayakan pasien perempuan jika pasien dalam keadaan darurat dan hanya dokter pria yang tersedia. Kasus di atas merupakan kasus sosial 
yang terjadi di masyarakat kita dan menggundang banyak kontroversi. Seorang pengiat media sosial Ade Armando, mencoba menyampaikan pendapatnya mengenai kasus di sebuah kanal Youtube yang Cokro TV. Pendapat dari Ade Armando memunculkan berbagai persepsi dan menjadi pembahasan di media lain. Beberapa orang beranggapan bahwa pendapat dari Ade Armando bersifat memojokkan atau menonjolkan satu pihak. Pendapat dari Ade Armando juga sering dianggap menjalankan kepentingan tertentu. Oleh karena itu dibutuhkan cara untuk mengungkap ideologi yang dimiliki Ade Armando pada saat memberikan opini terhadap kasuskasus sosial. Cara-cara tersebut dapat dilakukan dengan menggunakan analisis Theo Van Leeuwen.

Opini yang diungkapkan oleh Ade Armando merupakan sebuah wacana, karena wacana adalah buah pikir yang dihasilkan seseorang berisi satuan bahasa yang utuh. Wacana dapat berbentuk tulisan ataupun ujaran yang tersusun secara berurutan sesuai dengan tata bahasa yang dinggunakan. Wacana bersifat runtun, artinya ada hubungan antara wacana yang satu dengan wacana yang lain. Wacana bersifat multidiiplinier berdasarkan disiplin ilmu yang berbeda seperti gabungan bidang politik dan sosial. Pola-pola dalam wacana akan terbentuk berdasarkan bidangnya sendiri, contohnya wacana medis akan berbeda dengan wacana politik, sehingga topik yang dibicarakan juga akan berbeda-beda (Jorgensen dan Phillips 2007). Wacana memiliki keterkaitan dengan masyarakat, sebab wacana merupakan hasil interaksi dalam masyarakat dan terkait dengan situasi ataupun keadaaan yang sedang berlangsung. Wacana juga merupakan representasi dari pemikiran atau ide sekelompok orang, organisasi dan institusi. Dengan kata lain sebuah wacana bisa berisi sebuah ideologi ataupun dominasi dari kelompok tertentu. Jika sebuah wacana dikaji untuk mengungkap ideologi dalam wacana, maka kajian tersebut disebut analisis wacana kritis.

Kata kritis pada analisis wacana kritis berarti mencari celah masalah pada wacana yang diungkapkan. Analisis wacana kritis meluruskan sebuah wacana yang bersifat kontoversi, diskriminatif dan persuasif. Sebuah waacana yang kontroversi biasanya berkaitan dengan masalahmasalah yang berkembang di masyarakat seperti kesenjangan sosial, ketidaksetaraan gender, kemiskinan, kriminalitas dll. Lalu wacana yang manipulatif berisi argumentasi yang memarginalkan seseorang atau kelompok tertentu dan wacana persuasif berisi kata-kata atau kalimat yang mengajak seseorang untuk melakukan sesuatu hal yang dianggap bermanfaat. Renkema (2004) mengatakan analisis wacana kritis, secara kritis harus mampu mengangkat kalangan minoritas yang tidak memiliki kekuatan dan memberikan solusi dari masalah sosial yang berkembang dalam masyarakat.

Selanjutnya Wodak dan Meyer (2001) berpendapat bahwa analisis wacana kritis berkaitan dengan proses diskursif; yaitu proses produksi, distribusi dan konsumsi teks. Seseorang yang memproduksi wacana akan memiliki pengetahuan mengenai topik yang dibicarakan. Identitas sosial dalam wacana akan terlihat ketika wacana diproduksi dan ideologi yang diyakini juga terwakilkan. Ideologi menurut van Dijk (2006) berasal dari sebuah gagasan yang diketahui sebelumnya, yang diyakini dan dipercaya oleh seseorang atau sekelompok orang. Sebuah ideologi tidak mudah didapat dan dibagi begitu saja, tetapi membutuhkan proses pemahaman yang mendalam karena dihasilkan dari pengetahuan sosial, budaya dan agama. Ideologi juga berkaitan dengan norma dan nilai yang ada pada kehidupan sehari-hari berupa kebebasan, kesetaraan dan keadilan. Dapat disimpulkan bahwa analisis wacana mencoba mengkaji dan mengungkapkan ideologi dalam teks yang tersebunyi pada wacana berita, politik, sosial dll.

Wacana tidak hanya berada dalam sebuah teks penulisan dan ujaran tetapi juga pada kognisi sosial dari praktik sosial yang membangun konteks sosial seperti perusahaan, keluarga, institusi, pers dll (Titscher et al. 2000). Praktik sosial yang dilakukan oleh masyarakat dianalisis dalam analisis wacana kritis. Seperti apa yang dikatakan oleh Van Leeuwen (2008) sosial praktik berkaitan dengan bagaimana sebuah aturan dapat diterapkan. Aturan di sini berkaitan dengan 
aturan sehari-hari yang ada di masyarakat, contohnya mengajar, ketika mengajar pasti seorang guru mengetahui aturan ajar yang dikembangkan oleh ahli, memiliki sumber pengajaran dan mengetahui teknologi yang berkaitan dengan pengajaran. Sehingga dapat disimpulkan bahwa praktik sosial termasuk dalam elemen partisipan, tindakan, model yang ditampilkan, kondisi kelayakan partisipan, gaya yang ditampilkan, waktu, lokasi, kondisi kelayakan lokasi, sumber alat dan materi dan kondisi kelayakan sumber-sumber.

Van Leeuwen (2008) mengembangkan pengelompokkan aktor-aktor sosial dalam sebuah wacana. Para partisipan ini dikontekstualisasikan dalam praktik sosial tertentu. Dua kategori utama dalam pengelompokkan itu adalah inklusi dan eksklusi. Inklusi terjadi ketika aktor sosial ditunjukkan, dikenali dan diekspresikan dalam wacana, sedangkan eksklusi terjadi ketika aktor tidak termasuk dalam aktivitas praktik sosial. Ketika seorang aktor mengalami inklusi dalam sebuah wacana, maka aktor tersebut berada dalam posisi termajinalkan. Karena seseorang atau suatu kelompok dapat berada dalam posisi dimarjinalkan ketika tidak memiliki kekuasaan.

Penelitian yang menggunakan model analisis wacana kritis Theo Van Leeuwen telah banyak dilakukan, antara lain Mengungkap Ideologi Teks Berita Covid 19 Berdasarkan Pendekatan Analisis Wacana Kritis Theo Van Leeuwen oleh (Amalia et al., 2021). Artikel ini membahas ciri ideologi eksklusi, inklusi dan strategi eksklusi dan inklusi dalam pemberitaan Covid-19 mengenai tindak kejahatan dalam media daring SINDO news.com dan Fajar.co.id. Dalam penelitian itu ditemukan ciri ideologi eksklusi seperti pasivasi dan nominalisasi. Ciri ideologi inklusi seperti objektivasi, nominasi, identifikasi, determinasi, interdeterminasi, asimilasi dan individualisasi. Dan tiga perbedaan strategi inklusi dan eksklusi dalam media daring SINDO news.com dan Fajar.co.id. Berbeda dengan penelitian sebelumnya, penelitian selanjutnya berjudul Analisis Wacana Kritis Iklan Hari Tanpa Tembakau Sedunia 2020 Oleh Kementrian Kesehatan Republik Indonesia oleh (Tanfriana Stevanie, 2021). Artikel ini mengambarkan pesan dan ideologi yang disampaikan melalui unggahan Instagram Peringatan Hari Tanpa Tembakau Sedunia (HTTS) Kementrian Kesehatan Republik Indonesia. Dalam penelitian ini ditemukan beberapa ideologi seperti laki-laki lebih rentan menjadi perokok, rokok merupakan suatu hal yang buruk, media elektronik dapat menjadi pembujuk anak dan remaja untuk merokok dan media elektronik dapat dipakai untuk mengedukasi dampak buruk merokok. Penelitian berikutnya berjudul Critical Discourse Analysis of Theo Van Leeuwen's Inclusion Theory on Anti-Crime Editorials in Daily Newspaper Pos Kota February 2020 Edition oleh (Hartanto dan Rochmah 2020). Artikel ini membahas pemberitaan kriminalitas yang terdapat pada Surat Kabar Harian Pos Kota edisi Februari 2020 dengan mengkaji mengunakan analisis wacana kritis Theo Van Leeuwen. Dalam penelitian ini ditemukan tujuh strategi inklusi yaitu asimilasi, determinasi, disosiasi, indeterminasi, individualisasi, identifikasi dan kategorisasi. Lalu penelitian lainnya berjudul The Images and The Struggle of The 2018 Central-Java Local Government Election Reporting Meaning in Online Media Perceived by Theo Van Leeuwen Critical Discourse Analysis oleh (Parwaningtiyas, Mardikantoro, dan Joko Santoso, 2020). Artikel ini menganalisis image dari aktor-aktor sosial kandidat pemilihan gubernur Jawa Tengah tahun 2018 di dalam surat kabar Tribunnews.com, Kumparan.com dan Sindonews.com menggunakan teori analisis Theo Van Leeuwen. Dari hasil penelitian ini ditemukan bahwa Kumparan.com cenderung menerapkan penekanan dalam penggabungan aktor sosial. Sementara Tribunnews.com menerapkan latar belakang berupa "sang petahanan" atau "incumbent", sedangkan Sindonews.com tidak mengunggulkan atau memarginalkan aktor-aktor sosial tertentu.

Berbeda dengan penelitian sebelumnya, penelitian ini tidak hanya mengunakan teori analisis Van Leeuwen tetapi juga mengungkapkan ideologi yang dimiliki oleh Ade Armando. Berdasarkan paparan di atas, penelitian ini bertujuan untuk (1) mengungkapkan ideologi yang dimiliki oleh Ade Armando ketika dia memberikan pendapatnya, (2) menganalisis dan mendeskripsikan strategi inklusi dan eksklusi pada wacana logika Ade Armando yang bertema Kok Dokter Haram Pegang Pasien Perempuan yang dipublikasikan pada 30-September-2019 di kanal Youtube Cokro TV. 


\section{METODE PENELITIAN}

Penelitian ini menggunakan metode penelitian kualitatif. Metode penelitian kualitatif menurut Denzin dan Lincoln (1994) dalam (Emzir, 2018) menggunakan beberapa metode seperti interpertasi dan pendekatan fenomena secara khusus. Fenomena ini dianalisis untuk menemukan teori baru. Penelitian kualitatif meliputi pengumpulan sumber-sumber informasi seperti kisah nyata dalam kehidupan, wawancara dan masalah yang berkaitan dengan kehidupan. Salah satu teknik analisis data kualitatif adalah analisis isi. Menurut Bungin (2003) analisis isi difokuskan pada interpertasi simbol-simbol yang memiliki makna ganda, menimbulkan pendapat yang berbeda dan mengabungkan berbagai informasi dalam sebuah teks, salah satu contoh analisis isi adalah analisis wacana kritis.

Objek dari penelitian ini adalah dua buah video yang berjudul Kok Dokter Haram Pegang Pasien Perempuan yang diunduh pada tanggal 30-September-2019 di kanal Youtube Cokro TV. Video ini dipilih karena berkaitan dengan masalah sosial dan memiliki tema perempuan. Data penelitian adalah trankripsi video Kok Dokter Haram Pegang Pasien Perempuan. Metode analisis data berdasarkan teori pembeda (Distintion Theory Approach), bagian yang diamati adalah ujaran, kata, frase dan kalimat yang dinamai berdasarkan identitas pembeda (Titscher et al. 2000). Prosedur analisis data: (1) Penentuan unit analisis: menerapkan variable yang akan dianalisis seperti frase, kata, klausa dan kalimat. (2) Kategori dan koding berdasarkan identitas pembeda yaitu: eksklusi-inklusi, diferensiasi-indiferensiasi, objektivasi-abstraksi, nominasi-kategorisasi, nominasi-identifikasi, determinasi-indeterminasi, asimilasi-individualisasi dan asosiasi-disosiasi. (3) Menganalisis dan menginterpertasikan data. (4) Membuat kesimpulan.

\section{HASIL PENELITIAN DAN PEMBAHASAN}

Teks yang berjudul Kok Dokter Haram Pegang Pasien Perempuan berisi argumentasi Ade Armando terhadap masalah sosial bukan muhrim. Pada awalnya Ade Armando menerima keluhan dari temannya yang bekerja sebagai seorang dokter. Dokter tersebut merasa tidak sependapat dengan apa yang dikatakan oleh dosen ditempat anaknya kuliah. Dosen itu berkata bahwa seorang dokter pria itu haram menangani pasien wanita sebaliknya seorang dokter wanita juga haram menangani pasien pria. Ade Armando merasa keberatan dan memberikan berbagai pendapat yang berkaitan dengan hal tersebut.

Dari analisis data yang dilakukan, terlihat jelas bahwa pembicara memihak kepada dokter dan pasien perempuan secara umum dan juga pada dokter kandungan dan pasien perempuan yang sedang mengandung secara khusus. Selain itu juga ditemukan pihak yang dimarjinalkan, yaitu dosen agama Islam dan pria. Lalu peneliti menemukan strategi eksklusi dan inklusi pada teks yang berjudul Kok Dokter Haram Pegang Pasien Perempuan. Berikut jumlah strategi pemunculan dan penghilangan aktor yang ditemukan dalam teks:

Tabel 1. Strategi Eksklusi dan Inklusi

\begin{tabular}{|c|c|c|c|}
\hline $\begin{array}{l}\text { Strategi } \\
\text { Eksklusi }\end{array}$ & & Strategi Inklusi & \\
\hline Pasivasi & 3 & $\begin{array}{c}\text { Diferensiasi } \\
\text { Indiferensiasi }\end{array}$ & $\begin{array}{l}3 \\
3\end{array}$ \\
\hline Nominalisasi & - & $\begin{array}{l}\text { Objektivasi } \\
\text { Abstraksi }\end{array}$ & $\begin{array}{l}2 \\
2\end{array}$ \\
\hline $\begin{array}{l}\text { Penggantian } \\
\text { anak kalimat }\end{array}$ & - & $\begin{array}{c}\text { Nominasi } \\
\text { Kategorisasi } \\
\end{array}$ & $\begin{array}{l}3 \\
3 \\
\end{array}$ \\
\hline
\end{tabular}




\begin{tabular}{|c|c|c|c|}
\hline \multirow{4}{*}{} & Identifikasi & 7 \\
\cline { 3 - 4 } & Determinasi & 4 \\
& Indeterminasi & 3 \\
\cline { 3 - 4 } & Asimilasi & 1 \\
& Individualisasi & 1 \\
\cline { 3 - 4 } & & Asosiasi & - \\
& & Disosiasi & - \\
\hline Total & 3 & Total & 32 \\
\hline
\end{tabular}

Pada tabel diatas terlihat, strategi ekslusi hanya mengarah pada strategi pasivasi yang berjumlah 3, sedangkan strategi inklusi mengarah pada beberapa strategi yaitu diferensiasiindiferensiasi, objektivasi-abstraksi, nominasi-kategorisasi, determinasi-indeterminasi, asimilasiindividualisasi, asosiasi-disosiasi yang totalnya berjumlah 32. Pada tabel tersebut juga terlihat bahwa strategi diferensiasi sebanyak 3 kalimat, indifferensiasi 3 kalimat, objektivasi 2 kalimat, abstraksi 2 kalimat, nominasi 3 kalimat, kategorisasi 3 kalimat, identifikasi 7 kalimat, determinasi 4 kalimat, indeterminasi 3 kalimat, asimilasi 1 kalimat, individualisasi 1 kalimat dan tidak ditemukan strategi asosiasi dan disosiasi.

\subsection{Eksklusi}

Terdapat dua bagian pembeda dalam analisis wacana kritis (Van Leeuwen 2008), yaitu eksklusi dan inklusi. Eksklusi adalah proses pengeluaran dengan tidak menyebutkan aktoraktor sosial dalam teks. Strategi dari ekslusi adalah pasivasi, nominalisasi dan penggantian anak kalimat. Dari dua teks yang dianalis, penulis hanya menemukan strategi pasivasi. Pasivasi merupakan strategi pengubahan kalimat aktif menjadi kalimat pasif. Pada bentuk kalimat pasif ini aktor-aktor sosial tidak dimunculkan karena berbagai alasan seperti aktor tidak diketahui, tindakan dilakukan oleh aktor yang sama berulang-ulang, aktor merupakan pelaku yang umum diketahui orang banyak dan lain-lain. Contoh bentuk pasivasi bisa dilihat pada kalimat di bawah ini.

Tabel 2. Bentuk Pasivasi

\begin{tabular}{|l|l|}
\hline 1 & $\begin{array}{l}\text { Tapi kan ya terus terang saja niat baik saja tidak cukup kalau tidak diikuti } \\
\text { dengan akal sehat. }\end{array}$ \\
\hline 2 & $\begin{array}{l}\text { Jadi, kalau dilihat memang ada sih hadis-hadis yang kalau dibaca secara } \\
\text { literal memang mengharamkan pria bersentuhan dengan perempuan yang } \\
\text { bukan muhrim atau bukan istrinya. }\end{array}$ \\
\hline 3 & $\begin{array}{l}\text { Tapi kalau dokter, masa sih dokter dianggap melakukan kejahatan bila } \\
\text { berusaha membantu pasien perempuannya. }\end{array}$ \\
\hline
\end{tabular}

Pada kalimat pasif (1) Tapi kan ya terus terang saja niat baik saja tidak cukup kalau tidak diikuti dengan akal sehat. Pembicara menghilangkan aktor dari kata diikuti karena ingin menyamarkan pelaku dan menekankan pada ajakan pembicara yaitu bersifat bijaksana karena bagi pembicara mengatakan niat baik saja tidak cukup tetapi juga harus mempertimbangkan hal yang rasional antara situasi dan kondisi. Pada kalimat pasif (2) Jadi, kalau dilihat memang ada sih hadis-hadis yang kalau dibaca secara literal memang mengharamkan pria bersentuhan dengan perempuan yang bukan muhrim atau bukan istrinya. Aktor kalimat pasif tidak disebutkan karena pembicara menekankan pada tindakan dilihat dan dibaca. Pembicara mencoba menekankan dan meyakinkan jika dicermati dengan baik ada hadis-hadis yang mengharamkan pria bersentuhan dengan bukan muhrimnya. Pembicara juga menghilangkan aktor sosial pada kalimat ke dua karena aktor tersebut bersifat umum dan diketahui oleh semua orang yaitu umat muslim yang biasa membaca hadist. Pada kalimat pasif (3) Tapi kalau dokter, masa sih dokter dianggap melakukan kejahatan bila berusaha membantu pasien 
perempuannya. Aktor kalimat pasif tidak disebutkan karena pembicara membuat pendengar berpikir lebih kritis dengan menemukan siapa aktor yang sudah disebutkan dalam teks.

Dari proses eksklusi pada pendekatan penghilangan aktor-aktor sosial di dalam kalimat pasif, terlihat jelas bahwa pembicara menghilangkan aktor tersebut karena berusaha menyamarkan pelaku dan menekankan pada tindakan yang dilakukan aktor-aktor sosial itu. Pembicara melakukan hal tersebut agar tidak secara langsung memojokkan pelaku. Hal ini berbeda dengan kalimat aktif yang berfokus pada pelaku.

\subsection{Inklusi}

Sedangkan Inklusi adalah proses pemasukkan dengan menyebutkan aktor-aktor sosial dalam teks. Strategi inklusi adalah diferensiasi-indiferensiasi, objektivasi-abstraksi, nominasikategorisasi, nominasi-identifikasi, determinasi-indeterminasi, asimilasi-individualisasi dan asosiasi-disosiasi. (Eriyanto, 2001). Di dalam teks ini terdapat strategi diferensiasi, indeferensiasi, objektivasi, abstraksi, nominasi, kategorisasi, identifikasi, determinasi, indeterminasi, asimilasi, individualisasi tetapi tidak terdapat strategi asosiasi dan disosiasi.

a. Diferensiasi-indiferensiasi

Diferensiasi merupakan sebuah strategi yang secara tidak langsung membandingkan aktor-aktor sosial yang satu dengan yang lain di dalam teks. Strategi ini juga menunjukkan mana aktor yang lebih dominan, lebih baik ataupun sebaliknya. Adapun indiferensiasi menampilkan aktor yang tidak dibandingkan dengan aktor yang lain. Seperti contoh berikut ini:

Tabel 3. Diferensiasi dan Indiferensiasi

\begin{tabular}{|l|l|}
\hline \multicolumn{1}{|c|}{ Diferensiasi } & \multicolumn{1}{|c|}{ Indiferensiasi } \\
\hline $\begin{array}{l}\text { Para dosen itu barangkali berniat baik } \\
\text { mereka ingin mengajarkan ahlak mulia } \\
\text { pada pakak-anaknya, jada } \\
\text { mahasiswanya. }\end{array}$ & $\begin{array}{l}\text { Itu jadi haram karena si dokter } \\
\text { terpaksa harus memegang-megang } \\
\text { tubuh si pasien. }\end{array}$ \\
\hline $\begin{array}{l}\text { Nabi Muhammad pernah mengeluarkan } \\
\text { pernyataan yang Nampak kontroversial } \\
\text { tadi, tapi sangat mungkin yang dia } \\
\text { maksud tuh begini: "Wahai kaum pria, } \\
\text { jangan suka mengerayangi perempuan } \\
\text { ya." }\end{array}$ & $\begin{array}{l}\text { Jadi haram juga karena si dokter akan } \\
\text { melihat bagian-bagian tubuh lawan } \\
\text { jenis yang seharusnya tidak boleh } \\
\text { mereka lihat. }\end{array}$ \\
\hline $\begin{array}{l}\text { Tapi kalau dokter, masa sih dianggap } \\
\text { melakukan kejahatan bila berusaha } \\
\text { membantu pasien perempuannya? }\end{array}$ & $\begin{array}{l}\text { Tentu saja dia harus memeriksa } \\
\text { kandungan perempuan, jadi ini } \\
\text { bagaimana kalau itu dilarang? }\end{array}$ \\
\hline
\end{tabular}

Pada contoh kalimat diferensiasi, pembicara secara tidak langsung membandingkan aktor-aktor sosial yang satu dengan yang lain. Seperti pada kalimat (1) Para dosen itu barangkali berniat baik mereka ingin mengajarkan ahlak mulia pada anak-anaknya, pada mahasiswanya. Pembicara mencoba membandingkan posisi dosen dan mahasiswanya. Terlihat jelas pembicara lebih mendukung dosen karena bertugas sebagai pengajar. Pembicara juga menyisipkan kata anak-anaknya sebelum mahasiswa, ini menunjukkan bahwa mahasiswa yang diangap sebagai anak memiliki kedudukan lebih rendah daripada dosen. Berikutnya pada kalimat (2) Nabi Muhammad pernah mengeluarkan pernyataan yang nampak kontroversial tadi, tapi sangat mungkin yang dia maksud tuh begini: "Wahai kaum pria, jangan suka mengerayangi perempuan ya." Pada kalimat ini pembicara secara tidak langsung menunjukkan posisi nabi lebih tinggi dibandingkan umatnya dan secara tidak langsung mengatakan bahwa nabi Muhammad merupakan aktor yang lebih baik 
dibandingkan dengan pria yang mungkin suka mengerayangi perempuan. Lalu pada kalimat (3) Tapi kalau dokter, masa sih dianggap melakukan kejahatan bila berusaha membantu pasien perempuannya? Pada kalimat ini pembicara secara tidak langsung memberitahukan posisi dokter yang lebih tinggi daripada pasien perempuan, karena pembicara mengatakan bahwa dokter memiliki kemampuan untuk membantu pasien perempuan yang berada dalam posisi sakit atau tidak berdaya.

Pada contoh kalimat indiferensiasi, pembicara tidak membandingkan praktik sosial yang dilakukan aktor dalam teks dengan aktor-aktor lainnya. Seperti pada kalimat (1) Itu jadi haram karena si dokter terpaksa harus memegang-megang tubuh si pasien. (2) Jadi haram juga karena si dokter akan melihat bagian-bagian tubuh lawan jenis yang seharusnya tidak boleh mereka lihat. (3) Tentu saja dia harus memeriksa kandungan perempuan, jadi ini bagaimana kalau itu dilarang? Dokter di dalam tiga kalimat di atas tidak dibandingkan dengan aktor-aktor yang lain karena pembicara lebih menekankan pada pelaku.

Dari analisis strategi diferensiasi di atas dapat dilihat dengan jelas pembicara memiliki rasa hormat terhadap nabi Muhammad, profesi dosen dan dokter yang baginya tidak mungkin memarginalkan kedudukan keduanya. Dan dari analisis strategi indiferensiasi, pembicara secara tidak langsung menunjukkan bahwa dokter pria sebagai aktor sosial yang tidak bersalah karena memeriksa kandungan pasien wanita merupakan bagian dari pekerjaannya.

b. Objektivasi-abstraksi

Di dalam strategi objektivasi, aktor-aktor sosial memberi petunjuk atau informasi yang jelas. Sedangkan abstraksi aktor-aktor sosial tidak menampilkan petunjuk dan informasi yang jelas seperti menggunakan kata berulang-ulang sehingga maksudnya tidak tersampaikan. Berikut ini contohnya:

Tabel 4. Objektivasi dan Abstraksi

\begin{tabular}{|c|c|}
\hline Objektivasi & Abstraksi \\
\hline $\begin{array}{l}\text { Si dokter yang cerita pada saya itu } \\
\text { jelas sebel. Masalahnya dia itu dokter } \\
\text { ahli kandungan dan pasien dia } \\
\text { semuanya perempuan. }\end{array}$ & $\begin{array}{l}\text { Teman saya seorang dokter tentang } \\
\text { keluhan anaknya yang baru saja masuk } \\
\text { ke fakulttas kedokteran universitas } \\
\text { Indonesia. }\end{array}$ \\
\hline $\begin{array}{l}\text { Jadi, kalau dilihat memang ada sih } \\
\text { hadis-hadis dibaca secara literal } \\
\text { memang mengharamkan pria } \\
\text { bersentuhan dengan perempuan yang } \\
\text { bukan muhrim atau bukan istrinya. }\end{array}$ & $\begin{array}{l}\text { Anaknya bilang masa dosen di kuliah } \\
\text { agama Islam yang diikutinya bilang } \\
\text { begini dia bilang "Seorang dokter pria } \\
\text { itu haram menangani pasien wanita, } \\
\text { sebaliknya seorang dokter wanita juga } \\
\text { haram menangani pasien pria. }\end{array}$ \\
\hline
\end{tabular}

Pada contoh kalimat objektivasi di atas, kalimat (1) Si dokter yang cerita pada saya itu jelas sebel. Masalahnya dia itu dokter ahli kandungan dan pasien dia semuanya perempuan. Dalam kalimat ini pembicara menjelaskan dengan jelas alasan si dokter menjadi kesal yaitu dia tidak akan bisa memeriksa semua pasien perempuannya jika hal itu di nilai haram. (2) Jadi, kalau dilihat memang ada sih hadis-hadis dibaca secara literal memang mengharamkan pria bersentuhan dengan perempuan yang bukan muhrim atau bukan istrinya. Dalam kalimat kedua pembicara memberikan informasi yang jelas bahwa ada hadist yang menginformasikan bahwa pria tidak boleh bersentuhan dengan wanita yang bukan muhrim.

Pada contoh kalimat abstraksi di atas (1) Teman saya seorang dokter tentang keluhan anaknya yang baru saja masuk ke fakulttas kedokteran universitas Indonesia. Pada kalimat ini pembicara tidak memberikan penjelasan yang rinci apa yang dikeluhkan oleh anak temannya yang baru kuliah di UI. (2) Anaknya bilang masa dosen di kuliah agama Islam 
yang diikutinya bilang begini dia bilang "Seorang dokter pria itu haram menangani pasien wanita, sebaliknya seorang dokter wanita juga haram menangani pasien pria. Pada kalimat ke dua, pembicara mengulang kata bilang sebanyak tiga kali. Pengulangan kata ini membuat pendengar bingung dan menduga-duga apa yang akan dikatakan oleh pembicara. Kata dia bilang juga memiliki makna ganda, dia bisa berarti anak dokter tersebut atau dosen mata kuliah agama Islam.

Dapat disimpulkan bahwa pembicara lebih memilih memberikan informasi secara jelas dan rinci. Pembicara memberikan informasi yang tidak begitu jelas hanya pada awal pembicaraan untuk mengundang rasa ingin tahu pendengar.

c. Nominasi-kategorisasi

Pada strategi nominasi aktor-aktor sosial ditampilkan apa adanya. Berbeda dengan kategorisasi, yang mengaitkan aktor-aktor sosial dengan agama, ras, status, bentuk fisik dengan maksud memojokkan aktor atau kelompok sosial tertentu. Berikut ini contoh kalimat tersebut:

Tabel 5. Nominasi dan Kategorisasi

\begin{tabular}{|l|l|}
\hline \multicolumn{1}{|c|}{ Nominasi } & \multicolumn{1}{|c|}{ Kategorisasi } \\
\hline $\begin{array}{l}\text { Tentu saja dokter harus memeriksa } \\
\text { kandungan perempuan. }\end{array}$ & $\begin{array}{l}\text { Bayangkan kalau ada seorang dokter } \\
\text { ahli yang tidak mau menyelamatkan } \\
\text { pasien hanya karena perbedaan jenis } \\
\text { kelamin? }\end{array}$ \\
\hline $\begin{array}{l}\text { Atau maksudnya begini: "Tangan } \\
\text { kalian wahai kaum pria jangan gatel } \\
\text { ya!" }\end{array}$ & $\begin{array}{l}\text { Misalkan ada seorang perempuan yang } \\
\text { mau melahirkan tetapi dia tidak mau } \\
\text { ditangani oleh dokter laki-laki. }\end{array}$ \\
\hline $\begin{array}{l}\text { Si dokter yang cerita pada saya itu } \\
\text { jelas sebel. }\end{array}$ & $\begin{array}{l}\text { Kalau jumlah dokter ahli kandungan } \\
\text { pria itu kurang lebih seimbang dengan } \\
\text { perempuan sih barangkali tidak apa- } \\
\text { apa. }\end{array}$ \\
\hline
\end{tabular}

Pada contoh kalimat nominasi di atas, aktor-aktor sosial ditampilkan apa adanya tanpa dikaitkan dengan kelompok sosial tertentu. Misalnya (1) Tentu saja dokter harus memeriksa kandungan perempuan. Aktor dokter di sini ditampilkan apa adanya tanpa dikaitkan dengan hal lain, Begitu juga pada kalimat (2) Atau maksudnya begini: "Tangan kalian wahai kaum pria jangan gatel ya!" Pada kalimat ini pria yang menjadi aktor sosial ditampilkan apa adanya oleh pembicara. Dan kalimat (3) Si dokter yang cerita pada saya itu jelas sebel. Kalimat ke tiga aktor juga ditampilkan apa adanya, hal ini membuat pendengar lebih paham atas topik yang dibicarakan dan tidak harus memihak pada aktor sosial lainnya.

Pada contoh kalimat kategorisasi, pembicara mengaitkan satu aktor dengan aktor yang lain pada kelompok sosial tertentu. Seperti pada kalimat (1) Bayangkan kalau ada seorang dokter ahli yang tidak mau menyelamatkan pasien hanya karena perbedaan jenis kelamin? Di kalimat pertama ini secara tidak langsung pembicara mencoba menekankan ciri penting, yaitu pasien yang berbeda jenis kelamin. Lalu kalimat (2) Misalkan ada seorang perempuan yang mau melahirkan tetapi dia tidak mau ditangani oleh dokter laki-laki. Di kalimat ke dua pembicara memarginalkan kata perempuan. Dan pada kalimat (3) Kalau jumlah dokter ahli kandungan pria itu kurang lebih seimbang dengan perempuan sih barangkali tidak apa-apa. Pembicara mencoba memarginalkan dokter kandungan perempuan karena jumlahnya yang lebih sedikit dengan dokter kandungan wanita.

Dari analisis di atas dapat disimpulkan bahwa penggunaan strategi nominalisasi digunakan pembicara ketika pembicara menggunakan kalimat aktif dan fokus 
memberitahukan pelaku atau subjek pada kalimat apa adanya tanpa menghubungkan dengan aktor pada kelompok sosial tertentu. Lalu pembicara menggunakan strategi kategorisasi secara tidak langsung ketika ingin memberitahukan ciri kelompok sosial tertentu dan memarginalkan kelompok sosial tertentu.

d. Identifikasi

Pada strategi nominasi aktor-aktor sosial ditampilkan apa adanya. Adapun identifikasi, aktor-aktor sosial menggunakan anak kalimat penjelas untuk mendefinisikan kelompok, peristiwa atau tindakan tertentu. Pada contoh kalimat ini hanya menjelaskan bentuk strategi identifikasi karena strategi nominasi sudah di bahas sebelumnya. Berikut ini contoh strategi identifikasi:

Tabel 6. Identifikasi

Identifikasi

Teman saya seorang dokter tentang keluhan anaknya yang baru saja masuk ke fakulttas kedokteran universitas Indonesia.

Anaknya bilang masa dosen di kuliah agama Islam yang diikutinya bilang begini dia bilang "Seorang dokter pria itu haram menangani pasien wanita, sebaliknya seorang dokter wanita juga menangani pasien wanita.

Bayangkan kalau ada seorang dokter ahli yang tidak mau menyelamatkan pasien hanya karena perbedaan jenis kelamin?

Bayangkan juga kalau ada pasien yang tidak kunjung sembuh dari penyakitnya karena tidak bisa menemukan dokter yang berjenis kelamin sama.

Misalkan ada seorang perempuan yang mau melahirkan tetapi dia tidak mau ditangani oleh dokter laki-laki.

Kalau sudah begini saya paham kalau ada yang bilang agama bisa membawa keterbelakangan.

Saya sering mengangap bukan agamanya yang salah yang salah adalah orang yang tidak mau menggunakan akalnya ketika beragama.

Pada teks ini pembicara banyak menggunakan strategi identifikasi untuk memperjelas maksud pembicaraan dengan menambahkan anak kalimat. Misalnya pada kalimat (1) Teman saya seorang dokter tentang keluhan anaknya yang baru saja masuk ke fakulttas kedokteran universitas Indonesia. Pembicara memberikan penjelasan imengenai dentitas dari mahasiswa, agar pendengar percaya pada apa yang diceritakan oleh pembicara. Pada kalimat (2) Anaknya bilang masa dosen di kuliah agama Islam yang diikutinya bilang begini dia bilang "Seorang dokter pria itu haram menangani pasien wanita, sebaliknya seorang dokter wanita juga menangani pasien wanita. Pembicara memberikan informasi untuk meyakinkan pendengar bahwa siswa tersebut memang mengenal dosen agama Islam tersebut. Selanjutnya (3) Bayangkan kalau ada seorang dokter ahli yang tidak mau menyelamatkan pasien hanya karena perbedaan jenis kelamin? Pada kalimat ini pembicara memperjelas penjelasannya dengan menambahkan contoh tindakan yang tidak baik dilakukan oleh dokter yaitu tidak mau menyelamatkan pasiennya. Hal ini dilakukan pembicara agar pendengar memikirkan dampak yang terjadi pada pasien jika tidak diselamatkan oleh dokter. Berikutnya kalimat (4) Bayangkan juga kalau ada pasien yang tidak kunjung sembuh dari penyakitnya karena tidak bisa menemukan dokter yang berjenis kelamin sama. Kata yang pada kalimat ini digunakan oleh pembicara untuk memperjelas aktor pasien, yaitu pasien yang belum juga sembuh. Selanjutnya kalimat berikutnya (5) Misalkan ada seorang perempuan yang mau melahirkan tetapi dia tidak mau ditangani oleh dokter laki-laki. Pada kalimat kelima, pembicara menggunakan strategi identifikasi dengan 
menambahkan kata yang agar pendengar lebih yakin bahwa perempuan yang akan melahirkan benar-benar membutuhkan dokter kandungan laki ataupun perempuan. Pada kalimat (6) Kalau sudah begini saya paham kalau ada yang bilang agama bisa membawa keterbelakangan. Pada kalimat keenam, pembicara menggunakan strategi identifikasi untuk memarginalkan kata agama dan mengajak pendengar yakin bahwa memilih dokter berdasarkan jenis kelamin pasien merupakan hal yang tidak rasional. Dan kalimat berikutnya (7) Saya sering mengangap bukan agamanya yang salah yang salah adalah orang yang tidak mau menggunakan akalnya ketika beragama. Pada kalimat ke tujuh, pembicara mencoba memarjinalkan orang yang menggunakan agama karena tidak mau menggunakan akal. Pembicara juga meyakinkan pendengar bahwa agama tidak pernah salah tetapi orang yang menggunakan agama itu yang salah karena tidak berpikir secara logis.

Strategi identifikasi digunakan pembicara untuk memperjelas aktor-aktor sosial yang terlibat dengan memberikan penjelasan tambahan. Selain itu pembicara menggunakan strategi ini untuk memarginalkan aktor sosial yang terdapat pada kalimat dan meyakinkan pendengar untuk mengikuti apa yang diyakini oleh pembicara.

e. Determinasi-indeterminasi

Dalam strategi determinasi, aktor-aktor sosial yang ditampilkan menggunakan bentuk plural seperti sebagian orang dan banyak orang yang menimbulkan generalisasi dan ketidakjelasan, sedangkan indeterminasi menampilkan aktor-aktor yang jelas.

Tabel 7. Determinasi dan Indeterminasi

\begin{tabular}{|l|l|}
\hline \multicolumn{1}{|c|}{ Determinasi } & \multicolumn{1}{|c|}{ Indeterminasi } \\
\hline $\begin{array}{l}\text { Para dosen itu barangkali berniat baik } \\
\text { mereka ingin mengajarkan ahlak mulia } \\
\text { pada anak-anaknya, pada mahasiswanya. }\end{array}$ & $\begin{array}{l}\text { Itu jadi haram karena si dokter terpaksa } \\
\text { haru memegang-megang tubuh si } \\
\text { pasien. }\end{array}$ \\
\hline $\begin{array}{l}\text { Jadi, para dosen agama Islam itu rupanya } \\
\text { berlogika kalau menyentuh saja itu } \\
\text { haram luar biasa, apalagi memeriksa } \\
\text { tubuh perempuan yang bukan istrinya. }\end{array}$ & $\begin{array}{l}\text { Jadi haram juga karena si dokter akan } \\
\text { melihat bagian-bagian tubuh lawan jenis } \\
\text { yang seharusnya tidak boleh mereka } \\
\text { lihat. }\end{array}$ \\
\hline $\begin{array}{l}\text { Kalau jumlah dokter ahli kandungan pria } \\
\text { itu kurang lebih seimbang dengan } \\
\text { perempuan sih barangkali tidak apa-apa. }\end{array}$ & $\begin{array}{l}\text { Si dokter yang cerita pada saya itu jelas } \\
\text { sebel. }\end{array}$ \\
\hline $\begin{array}{l}\text { Tapi kan masalahnya jumlah dokter ahli } \\
\text { kandungan pria pasti jauh lebih banyak. }\end{array}$ & \\
\hline
\end{tabular}

Strategi determinasi pada kalimat (1) Para dosen itu barangkali berniat baik mereka ingin mengajarkan ahlak mulia pada anak-anaknya, pada mahasiswanya. Pembicara menggunakan kata para di dalam kalimat satu untuk mengaburkan aktor sosial sehingga tidak jelas siapa aktor sosialnya dan mencoba mengeneralisasikan dosen siapapun. Sama halnya pada kalimat (2) Jadi, para dosen agama Islam itu rupanya berlogika kalau menyentuh saja itu haram luar biasa, apalagi memeriksa tubuh perempuan yang bukan istrinya. Kata para digunakan untuk menampilkan aktor sosial secara tidak jelas yang berdampak pada pelaku yang bersifat umum yaitu semua dosen agama Islam. Begitu juga pada kalimat (3) Kalau jumlah dokter ahli kandungan pria itu kurang lebih seimbang dengan perempuan sih barangkali tidak apa-apa. Pembicara tidak memberitahukan dengan jelas jumlah dokter pria dan dokter perempuan yang membuat aktor sosial menjadi anonim atau tidak jelas. Begitupun pada kalimat (4) Tapi kan masalahnya jumlah dokter ahli kandungan 
pria pasti jauh lebih banyak. Pada kalimat keempat penggunaan frase jauh lebih banyak memiliki dampak yang tidak jelas pada pelaku aktor sosial.

Sedangkan strategi indeterminasi pada kalimat (1) Itu jadi haram karena si dokter terpaksa harus memegang-megang tubuh si pasien. Kata si digunakan oleh pembicara untuk memperjelas aktor sosial yang terlibat dalam pembicaraan. Begitupun pada kalimat (2) Jadi haram juga karena si dokter akan melihat bagian-bagian tubuh lawan jenis yang seharusnya tidak boleh mereka lihat. Kalimat kedua pembicara juga menggunakan kata si untuk menunjukkan aktor sosial dengan jelas dan tidak memihak pada aktor sosial yang lain. Dan kalimat (3) Si dokter yang cerita pada saya itu jelas sebel. Pembicara menggunakan kata si memperjelas aktor sosial yang merasa tidak senang atau kesal pada pendapat bukan muhrim yang diceritakan sebelumnya oleh pembicara.

Dapat disimpulkan bahwa kedua strategi di atas merupakan strategi yang berbeda yang digunakan oleh pembicara untuk menjelaskan aktor sosial yang terlibat di dalam teks. Aktor sosial dengan bentuk plural dengan menggunakan kata para membuat aktor sosial bersifat tidak spesifik mengacu pada orang tertentu, sehingga pendengar dapat langsung mengeneralisasikannya. Sedangkan aktor sosial dengan bentuk singular dengan menggunakan kata si membuat aktor sosial bersifat lebih spesifik pada orang tertentu.

f. Asimilasi-individulisasi

Pada strategi asimilasi tempat aktor sosial berada ditunjukkan sehingga terjadi efek generalisasi. Sedangkan individualisasi aktornya ditampilkan dengan jelas secara individual dan spesifik. Berikut contoh dari kalimat tersebut:

Tabel 7. Asimilasi dan Individualisasi

\begin{tabular}{|c|c|}
\hline Asimilasi & Individualisasi \\
\hline $\begin{array}{l}\text { Dan ini juga terjadi karena ada } \\
\text { doktrin bahwa perempuan sebaiknya } \\
\text { bekerja mengurus rumah saja. }\end{array}$ & $\begin{array}{l}\text { Teman saya seorang dokter tentang } \\
\text { keluhan anaknya yang baru saja } \\
\text { masuk ke fakulttas kedokteran } \\
\text { universitas Indonesia. }\end{array}$ \\
\hline
\end{tabular}

Pada dua kalimat di atas, terdapat perbedaan strategi asimilasi dan strategi individualisasi. Strategi asimilasi terdapat pada kalimat (1) Dan ini juga terjadi karena ada doktrin bahwa perempuan sebaiknya bekerja mengurus rumah saja. Keberadaan aktor perempuan dalam kalimat ini disebutkan di rumah, jadi ada generalisasi bahwa perempuan hanya bisa berada dan bekerja di rumah saja. Sedangkan pada kalimat kedua yaitu (2) Teman saya seorang dokter tentang keluhan anaknya yang baru saja masuk ke fakulttas kedokteran universitas Indonesia. Pada kalimat kedua tidak terjadi generalisasi melainkan lebih spesifik pada aktor sosial tertentu karena ada penggunaan kata seorang. Seorang pada kalimat ini berkaitan dengan teman pembicara yang baru kuliah di fakultas kedokteran UI. Dapat disimpulkan bahwa pembicara menggunakan strategi asimilasi untuk mengeneralisasikan perempuan tidak harus bekerja sebagai seorang dokter tetapi berada di rumah saja. Sedangkan strategi individualisasi digunakan pembicara untuk menonjolkan aktor sosial sendiri tanpa menampilkan aktor sosial lainnya.

g. Asosiasi-disosiasi

Pada strategi asosiasi aktor-aktor sosial menghubungkan dengan komunitas yang lebih besar, tempat aktor sosial itu berada. Sedangkan disosiasi aktor-aktor sosial ditampilkan sendiri tanpa dihubungkan dengan kelompok yang lebih besar. Tidak terdapat strategi asosiasi dan disosiasi pada teks ini. 


\section{KESIMPULAN}

Berdasarkan tujuan penelitian dan rumusan masalah yang terlah disebutkan sebelumnya, maka dapat disimpulkan ideologi yang digunakan oleh pembicara memihak pada dokter khususnya dokter kandungan dan pasien perempuan. Pembicara mencoba mengajak dan meyakinkan pendengar bahwa aktor sosial seperti pasien perempuan atau laki-laki membutuhkan seorang dokter tanpa perlu memilih jenis kelamin apapun untuk kepentingan pasien tersebut.

Strategi eksklusi di dalam teks ini lebih mengarah pada strategi wacana pembentukan kalimat pasif, sedangkan strategi inklusi lebih mengarah pada strategi wacana identifikasi. Pembicara lebih banyak menggunakan strategi pengeluaran aktor dengan menggunakan wacana pasivasi untuk lebih fokus pada tindakan yang dilakukan aktor-aktor sosial, sebaliknya pembicara lebih banyak menggunakan strategi wacana identifikasi untuk memberikan penjelasan lebih pada aktor-aktor yang terlibat di dalam teks. Diharapkan penelitian berikutnya dapat mengaitkan strategi inklusi dan eksklusi dengan teori persuasif, karena di dalam teks ini pembicara secara tidak langsung mengajak pendengar untuk mengikuti apa yang diyakini oleh pembicara.

\section{DAFTAR PUSTAKA}

Amalia, Resky, Program Pascasarjana, Magister Pendidikan, and Universitas Negeri Makassar. 2021. "Berdasarkan Pendekatan Analisis Wacana Kritis." 17(2): 203-15.

Bungin, Burhan. 2003. Analisis Data Penelitian Kualitatif. Jakarta: PT RajaGrafindo Persada. van Dijk, Teun A. 2006. "Ideology and Discourse Analysis." Journal of Political Ideologies 11(2): $115-40$.

Emzir. 2018. Metodologi Penelitian Kualitatif Analisis Data. 6th ed. Depok: RAJAWALI PERS. Eriyanto. 2001. Analisis Wacana: Pengantar Analisis Teks Media. Yogyakarta: LKiS.

Hartanto, Bagus Hady, and Erlina Chamalia Rochmah. 2020. "Critical Discourse Analysis of Theo Van Leeuwen' s Inclussion Theory on Anti-Crime Editorials in Daily Newspapers Pos Kota February 2020 Edition." 4: 119-26.

Jorgensen, Marianne W, and Louise J Phillips. 2007. "Analisis Wacana: Teori Dan Metode." Yogyakarta: Pustaka Pelajar.

Van Leeuwen, Theo. 2008. Discourse and Practice New Tools for Critical Discourse Analysis. New York: Oxford University Press.

Parwaningtiyas, Anung Anindita, Hari Bakti Mardikantoro, and Bernadus Wahyudi Joko Santoso. 2020. "The Images and The Struggle of The 2018 Central-Java Local Government Election Reporting Meaning in Online Media." Seloka: Jurnal Pendidikan Bahasa dan Sastra Indonesia 9(2): 99-109.

Renkema, Jan. 2004. Introduction to Discourse Studies. Philadelphia, USA: John Benjamins North America.

Tanfriana Stevanie, Kezia. 2021. "2020 ADVERTISEMENT BY INDONESIAN MINISTRY OF HEALTH."

Titscher, Stefan, Michael Maayer, Ruth Wodak, and Vetter Eva. 2000. Methods of Text and Discourse Analysis. London: SAGE Publications.

Wodak, Ruth, and Michael Meyer. 2001. Critical Discourse Analysis. eds. Ruth Wodak and Michael Meyer. London: SAGE Publications.

Amalia, Resky, Program Pascasarjana, Magister Pendidikan, and Universitas Negeri Makassar. 2021. "BERDASARKAN PENDEKATAN ANALISIS WACANA KRITIS." 17(2): 203-15. Bungin, Burhan. 2003. Analisis Data Penelitian Kualitatif. Jakarta: PT RajaGrafindo Persada. van Dijk, Teun A. 2006. "Ideology and Discourse Analysis." Journal of Political Ideologies 11(2): $115-40$.

Emzir. 2018. Metodologi Penelitian Kualitatif Analisis Data. 6th ed. Depok: RAJAWALI PERS. 
Eriyanto. 2001. Analisis Wacana: Pengantar Analisis Teks Media. Yogyakarta: LKiS.

Hartanto, Bagus Hady, and Erlina Chamalia Rochmah. 2020. "Critical Discourse Analysis of Theo Van Leeuwen's Inclussion Theory on Anti-Crime Editorials in Daily Newspapers Pos Kota February 2020 Edition." 4: 119-26.

Jorgensen, Marianne W, and Louise J Phillips. 2007. “Analisis Wacana: Teori Dan Metode." Yogyakarta: Pustaka Pelajar.

Van Leeuwen, Theo. 2008. Discourse and Practice New Tools for Critical Discourse Analysis. New York: Oxford University Press.

Parwaningtiyas, Anung Anindita, Hari Bakti Mardikantoro, and Bernadus Wahyudi Joko Santoso. 2020. "The Images and The Struggle of The 2018 Central-Java Local Government Election Reporting Meaning in Online Media." Seloka: Jurnal Pendidikan Bahasa dan Sastra Indonesia 9(2): 99-109.

Renkema, Jan. 2004. Introduction to Discourse Studies. Philadelphia, USA: John Benjamins North America.

Tanfriana Stevanie, Kezia. 2021. "2020 ADVERTISEMENT BY INDONESIAN MINISTRY OF HEALTH."

Titscher, Stefan, Michael Maayer, Ruth Wodak, and Vetter Eva. 2000. Methods of Text and Discourse Analysis. London: SAGE Publications.

Wodak, Ruth, and Michael Meyer. 2001. Critical Discourse Analysis. eds. Ruth Wodak and Michael Meyer. London: SAGE Publications. 